\title{
ORGANISATIONAL CAPACITIES AND MANAGEMENT OF AGRICULTURAL EXTENSION SERVICES IN NIGERIA: CURRENT STATUS
}

\author{
Davis, K. ${ }^{1}$, Lion, K. ${ }^{2}$ and Arokoyo, T. ${ }^{3}$ \\ Correspondence author: K. Davis. Mail: K.Davis@cgiar.org
}

\section{ABSTRACT}

Organisational capacity and management are critical elements of extension systems. This paper examines the organisational capacity and management of the Nigerian extension system. Content analysis of documents and artefacts, semi-structured interviews with key informants, and site visits were used to collect data. The paper looks at individual, organisational, and system-level capacities and management systems. The current ratio of extension agents to farmers is between 1:5000 and 1:10 000, with a total workforce of about 7000 public agents. A new initiative, the N-Power programme, is employing 100000 young graduates in extension. Financing provided by state governments typically only covers the salaries of extension staff, meaning there is little operational budget for travel, communication, training, or field programmes. States thus struggle to hire and provide incentives for staff, and most continuing education and incentives take place in donor-funded projects or with federal funds. The extension system has good support from policies and strategies, as well as from research, education, and donor programmes. The paper confirms that capacity and management issues are critically important for well-functioning extension systems, and that there are many elements to get right, including continuing education, incentives, coordination, and operational budgets.

Keywords: Capacity, Extension, Management, Nigeria, Organisations

\section{INTRODUCTION}

There is new focus on agriculture and extension services in Nigeria, and it is thus important to understand the status of the system, including one major component, namely the organisational capacities and management. This paper thus analyses the capacities and management of the current Nigerian pluralistic extension system.

Until the early 1970s, Nigeria was self-sufficient in food production, and agriculture was the main source of foreign exchange earnings. Following the discovery of oil, the agriculture sector stagnated as resources were shifted to develop the petroleum industry (World Bank, 2016). Nigeria now spends approximately US $\$ 6.5$ billion annually in food imports (Matsilele, 2017).

Support to public agriculture and to extension services has fluctuated in response to the overall political and economic environment in the decades following independence. However, in 2013, the Nigerian government instituted the National Economic Transformation Agenda to "diversify the economy from reliance on oil, assure food security and create jobs, especially

\footnotetext{
${ }^{1}$ Senior Research Fellow, International Food Policy Research Institute, c/o University of Pretoria, Department of Agricultural Economics, Extension and Rural Development, Private Bag X 20 Hatfield 0028, South Africa.

${ }^{2}$ Director, Global Agriculture Strategy, Digital Green, San Francisco, 650 California St., 7th Floor, San Francisco, CA 94108, USA.

${ }^{3}$ Professor, Ahmadu Bello University, Zaria, Nigeria.
} 
for the youth" (African Development Bank (ADB), 2013:3). At the same time, the Federal Ministry of Agriculture and Rural Development (FMARD) initiated the Agricultural Transformation Agenda to "promote agribusiness, attract private sector investment in agriculture, reduce post-harvest losses, add value to local agricultural produce, develop rural infrastructure, and enhance access of farmers to financial services and markets" (ADB, 2013:3).

As the government begins to focus on and reinvest in agricultural extension services, it is important to take stock of the current extension system, especially with regards to the organisational capacity and management of the system. Capacities are a critical element of extension systems. They are more crucial than ever to deal with today's challenges such as climate change and globalisation. Extension is no longer seen as a linear link in the chain of transfer of technology, but rather as a broker and facilitator within complex agricultural innovation systems (Davis \& Sulaiman, 2014). This implies the need for new capacities in extension. The government is beginning to focus on this with the N-Power programme, which is highlighted in the results.

Capacities are not just important at the individual (extension agent) level, but at the organisational and system (or enabling environment) levels too (Food and Agriculture Organization (FAO), 2016). The individual level "relates to knowledge, skills (technical and managerial), and attitudes that can be addressed through facilitation, training, and competency development" (FAO, 2016:4). The organisational level "relates to public, private, and civil society organisations and networks of organisations in terms of a) strategic management functions, structures, and relationships; b) operational capacity (relationships, processes, systems, procedures, sanctions, incentives, and values); c) human and financial resources (policies, deployment, and performance); d) knowledge and information resources; and e) infrastructure" (FAO, 2016:4). Finally, the system level "relates to political commitment and vision; policy, legal, and regulatory and economic frameworks; national public-sector budget allocations and processes; governance and power structures; infrastructure; incentives; and social norms" (FAO, 2016:4).

Management of extension services has received little attention in previous literature (Birner et $a l, 2009)$. A variety of management tools can be used to improve the performance of public service provision. These include Total Quality Management, Quality Circles, Results-Based Management, Best Value, and Benchmarking (Birner et al., 2009). Public-sector management reforms of the last decades have mainly fallen under 'New Public Management' (NPM), which applies private sector management approaches to the public sector. Along with other extension reforms such as decentralisation, privatisation, and demand-driven and participatory approaches, NPM is output and results-oriented, customer-driven, and efficiency-focused (Bertucci \& Jemiai, 2000). In extension services, this would affect performance management and accountability mechanisms.

For the purpose of this paper, we focus on the organisational capacities, that is, the staff numbers, training level, and skills; financing; and capabilities of the organisations and systems to perform their tasks. We also focus on the management, including performance incentives, accountability, and monitoring and evaluation of the services. 
S. Afr. J. Agric. Ext.

Vol. 47 No. 2, 2019: 118 - 127

http://dx.doi.org/10.17159/2413-3221/2019/v47n2a508
Davis, Lion,

Arokoyo

(License: CC BY 4.0)

\section{METHODOLOGY}

Content analysis of documents and artefacts, semi-structured interviews with key informants, and site visits were used to collect data for the study. Key informants were from government, research institutions, non-governmental organisations, donor projects, and the private sector. A total of 27 key informants were interviewed at their offices in Abuja or Zaria, where several of the interviews had multiple participants (between 1-5 people). Three of the discussions were with larger groups of participants in Abuja, Zaria, and Kaduna (21, 48 and 25 respectively). The Abuja meeting was conducted with Federal Ministry of Agriculture and Rural Development (FMARD) personnel. Zaria meetings included key stakeholders in the region in one meeting, and a visit to an "adopted" village to talk to participating farmers. The Kaduna meeting was with state-level personnel and the private sector. The documents reviewed were from both peer-reviewed academic sources as well as project documents and other grey literature. Validity was ensured through triangulation with individuals, groups, and organisations (Ary, Jacobs \& Razavieh, 1996). Debriefing with peers, member checks, and using expert consultants also helped to ensure validity (Ary et al, 1996). Triangulation also helped to ensure reliability.

\section{RESULTS}

Capacities and management are important components of extension, providing the framework, tools, and facilities to implement programmes. They include human and physical resources, education and training, skills and capabilities, coordination, and programme financing. In a pluralistic system, this is a shared role between the public, private, and civil society sectors. We highlight the individual, organisational, and system-level capacities, as well as management issues such as accountability and coordination.

\subsection{Individual-level capacities}

Individual-level capacities include competencies, skills (technical and managerial), and attitudes. This includes the overall human resources or staffing of the extension system. According to a group interview with FMARD, approximately 7000 agents are employed in the public system in Nigeria. Estimates for the current ratio of extension agents to farm families vary from 1:5000 to 1:10 000, even within FMARD. Furthermore, 28\% of extension agents are female and $60 \%$ are over the age of 40 , demonstrating the aging of the extension workforce and lack of new hires.

The majority of public extension agents undergo specialised training in agricultural extension. The first level includes an Ordinary National Diploma - an additional two years after high school, followed by a Higher National Diploma (HND) - an additional two years after the Ordinary Diploma. The next level is the Bachelor of Science (BSc) degree in agricultural extension, which entails five years of schooling following high school. Most of the field extension agents have an Ordinary National Diploma in most states in the north, and most in the southern states have an HND. Most of this training focuses on the basics of crop or livestock science, with insufficient attention to post-harvest management, business and market elements, or functional skills such as communication and group facilitation.

Based in Zaria with six zonal offices, the Nigerian Agricultural Extension Research and Liaison Services (NAERLS) is also responsible to train and develop extension providers around the 
country, but struggle with inadequate funding for most of its programmes (FMARD group interview, 2016). NAERLS provides training to the 36 state-level Agricultural Development Programmes (ADPs). However, ADPs typically do not have funds to travel to NAERLS for training. Usually only five agents from each state come to the training session, with more coming from whichever state the training is hosted in. In addition, the Agriculture and Rural Management Training Institute also provides extension training. Some states have gone 30 years without training their ADP extension agents and 25-30 years without new recruitment (Government stakeholder, 2016).

Most public extension agents in Nigeria are employed through the state-level ADPs. The ADP offices were set up during the 1990s with World Bank assistance. During the period of the World Bank-funded ADPs, the average ratio of extension agents to farm families was 1:10001500. Extension agents were both directly recruited and seconded from the respective states' Departments of Agriculture. Following the withdrawal of World Bank funding, massive attrition of both permanent and contract staff occurred. The deterioration in the quantity and quality of staff also led to a deterioration of quality of services (Technical Centre for Agricultural and Rural Cooperation (CTA), 2011). Attrition of state-level ADP staff has also been high due to poor working conditions (CTA, 2011).

The Kaduna State ADP is considered the best-functioning ADP in Nigeria (Huber, Davis \& Lion, 2017). Farming is the main source of income for most people in Kaduna, so the state government has been relatively supportive of the ADP. However, Kaduna ADP struggles to provide basic extension services. Currently, they have 129 agents, giving them a ratio of one agent to 4700 farming families. They have 40 motorcycles, largely funded by donor projects, but there is no fuel allowance, except through donor projects. The NAERLS provides fortnightly training for agents, but the ADP representatives felt the training was not up-to-date, too short, and lacking in field demonstrations to complement classroom training.

As a new initiative to improve youth employment opportunities in the country, the federal government launched the N-Power Programme in 2016 to hire 500000 young people, aged 18 to 35, to work in education, health, and agriculture. N-Power Agro (which focuses on extension services) set targets for 100000 recruits. The recruits receive basic training plus two years' practical experience on the job, while being paid a flat stipend by the federal government (around US \$100 per month). The programme refers to them as 'paid volunteers' (Federal Government of Nigeria (FGN), 2016). Since this programme is under the current political administration, it is not clear whether it will be continued when the next administration takes office in 2019.

The federal government used a private agency for the recruitment and selection of N-Power Agro candidates for each state. The employment scheme used a phased approach with 30000 hired in Phase I (year 1), 30000 in Phase II, and 40000 in Phase III. By early 2016, 57000 people had applied for agriculture or extension positions. The government is targeting a 50:50 ratio for men to women, but the response from women has not met this target and the programme started using women-specific recruiting advertisements in 2017 (Government stakeholder, 2016).

The N-power Agro training for master trainers has been completed in all states and the Federal Capital Territory. The first tranche of 30000 volunteers were trained in 2017 for three to four weeks at the local governments where they will work in many states. However, not all the states 
have initiated training due to funding constraints and the level of commitment of the various states. Nevertheless, each of the 774 local governments received approximately 38 volunteers. Budget was allocated for stipends, and the government procured tablets for each recruit. Recruits started on the ground under the local governments in 2017 (Government stakeholder, 2016).

The training curriculum for N-Power Agro was developed with the non-governmental organisation Sasakawa, NAERLS, and agricultural universities and research institutes. The curriculum was reviewed at the end of 2016 by the private sector, in part to get their buy-in. The federal government wants the private sector and state governments to employ the young people after their two-year stint, though few companies have shown an interest in this and state governments are barely able to pay their existing staff with the recession. Eventually, FMARD would like to establish a permanent training school and system that will continue to train young graduates. Continuing education of the new hires is desired, and some mentorship will be provided. In addition, there is a plan for a virtual support platform that agents can use to send in queries and obtain advice from experts from the universities and research institutes (Government stakeholder, 2016).

Each state ADP has a focal officer to coordinate with the N-Power volunteers. While the volunteers will be based at the ADP offices, they will not report directly to the ADPs and will be managed federally. Work planning and performance management of so many new staff will be a challenge and such a massive hiring and training programme can only be judged over time. Past experience in Nigeria and evidence from literature shows that hiring and paying salaries is only one part of an extension service, therefore, operational funds, continuing education, and strong links with knowledge actors are all critical elements that must also be provided for (Government stakeholder, 2016).

The donor-funded Sasakawa Africa Fund for Extension Education (SAFE) does provide the opportunity for mid-career extension professionals to obtain university degrees. Their employers are also required to contribute to the programme. SAFE started in 2003 at Ahmadu Bello University and now includes four universities in Nigeria. Some 379 extension professionals have completed the mid-career BSc programme (SAFE, 2017).

Nigerian extension has a strong culture of professional development in academia. The Agricultural Extension Society of Nigeria provides opportunities for extension academics and practitioners to collaborate in strengthening extension in Nigeria. However, there is no overall certification, set of standards, or regulation for extension agents from all sectors that would ensure quality and professionalism of the extension services. The recently-formed Nigerian Forum for Agricultural Advisory Services has taken up this topic, but have yet to institute any specific mechanisms (Government stakeholder, 2016).

\subsection{Organisational-level capacities}

Organisational-level capacities include financing, equipment and infrastructure, performance management, and knowledge and information resources. Practically, the federal government provides the majority of funding for extension today, and state governments do most of the execution. According to FMARD, only Kaduna and Anambra states are directly funding their ADPs, while the rest rely on donor projects. 
Financing provided by state governments typically only covers the salaries of ADP extension staff, leaving little or no operational budget for travel, communication, training, or field programmes with farmers (CTA, 2011). This results in a lack of motivation and inadequate training and preparation with regards to modern agriculture extension. The ADPs within each state are organised into zones, then sub-zones, then blocks (which are approximately equal to a Local Government Area (LGA) and are the smallest formal administrative government unit in Nigeria), and then cells (or villages). Since the ADPs were designed to be funded through a tri-partite agreement between the World Bank (66\%), federal government (20\%), and state government (14\%), they were set up somewhat in parallel to the existing agriculture department at the LGA level and expected to collaborate (Auta \& Dafwang, 2010). There is an expectation that the LGAs provide some level of extension services, but there is variability in the services they provide, and ADP agents typically fill the gaps. Unfortunately, there is little to no coordination between ADP staff and LGA agricultural staff (FMARD, 2016). Furthermore, the local governments have no regular budget to rely on, and only receive funds for special agricultural projects.

Over $60 \%$ of extension agents have smart phones that could be used to support activities, but no allowance for data or communication costs or tools to use on their phones. Despite the limitations regarding the ADPs, there are some examples of states and other actors providing resources to reinvigorate it:

- The Labana rice mill in Kebbi State purchased 25 motorcycles for extension agents with a monthly fuel allowance (Donor/ project stakeholder, 2017).

- Delta State has provided 71 motorcycles to extension agents.

- Kano state recently hired 740 new agents, 100 of whom were trained by a donor project collaboration with the International Crops Research Institute for the Semi-Arid Tropics and Sasakawa.

- Several donor-funded programmes provided comprehensive training (workshops conducted on pre-season, post-harvest, group formation and dynamics, and leadership skills to build capacity) and gave stipends to select extension agents working on their projects, which has boosted enthusiasm and enhanced results (Government stakeholder, 2016.)

The state-level ADPs and other extension providers were not found to have adequate, if any, systems of performance management and little incentives for staff beyond the basic salary. Those agents working with donor-funded programmes sometimes have access to transport and limited operational funds. Furthermore, monitoring and evaluation systems are weak or nonexistent. However, the new extension policy does highlight the importance of monitoring and evaluation as well as accountability.

With regards to knowledge management, NAERLS is responsible for Nigeria's market information services, which involves regularly collecting and disseminating market prices of commodities in selected markets in all the geopolitical zones. They are also implementing a farmer helpline and an e-extension system.

\subsection{System-level capacities}

System-level capacities include vision and political commitment; policy, legal, and strategic frameworks; national public-sector budget allocations and processes; and governance and 
S. Afr. J. Agric. Ext.

Vol. 47 No. 2, 2019: 118 - 127

http://dx.doi.org/10.17159/2413-3221/2019/v47n2a508
Davis, Lion,

Arokoyo

(License: CC BY 4.0)

power structures. While government revenues to support programmes are currently low due to the recession, there is a renewed focus and political will in both agriculture and extension. Several policies and programmes support agriculture with new initiatives involving extension services. In addition to the N-Power Agro programme, this shift can be seen from the Growth Enhancement Support Scheme, which launched a system to distribute fertilizer subsidies directly to farmers through mobile money. Another indication is the Agriculture Promotion Policy, which highlights the need to fund, coordinate, and improve quality of extension services across the country. In extension, this increased support is evidenced through the development of a new extension policy and the establishment of the Federal Department of Agricultural Extension Services in December 2012.

With regards to governance structures and the enabling environment for extension, Nigeria has an impressive infrastructure, including dedicated extension offices in each state, a large number of agricultural research institutions and extension training programmes, as well as a coordination system connecting research and extension to farmers called the ResearchExtension-Farmer-Input Linkage System (REFILS). Most of these structures were established with World Bank funding in the 1980s and have since suffered from a severe lack of funding and coordination in times of both economic growth and recession.

The extension system is supported by an extensive agricultural research and education system. Nigeria has the largest agriculture research system in sub-Saharan Africa, with 2688 agricultural researchers and spending US \$550 million for research (Agricultural Science and Technology Indicators (ASTI), 2014). The connection between research, extension agents, and farmers is generally considered weak. Key research organisations include the 17 commoditybased research institutes, the National Agricultural Extension Institute, agriculture departments in 18 national universities, three specialised universities of agriculture, and an international agricultural research centre (CTA, 2011).

Pluralism, especially in the private sector, has been growing. Various initiatives across public, private, and non-governmental actors point to increased pluralism within the extension system. The World Bank Fadama Project is the largest donor project currently working in agricultural extension, and has contracts with both private advisory service providers and public agencies. Sometimes the non-public providers, such as Sasakawa Africa Association, hire extension agents from ADPs to staff the project. A variety of other donor projects also hire ADP staff to implement extension activities. Typically, this is not in conflict with their government duties, but simply provides travel, communication and programmatic funding, plus training to do basic extension work that they would not normally be able to.

In terms of coordination of pluralistic actors, the REFILS is intended to bring together research, extension, the private sector, and farmers to ensure that new research is used and to guide the course of future public research. The World Bank's National Agricultural Research Project initially funded REFILS from 1995 to 2000 to good performance, primarily defined by strong communication channels between researchers and extension, researchers and farmers, and extension and farmers. However, following the ending of the World Bank's funding, REFILS performance declined, due to both a lack of funding and coordination (CTA, 2011).

REFILS' activities by NAERLS today include quarterly review meetings in each zone, an annual review meeting, feedback on the Agricultural Performance Survey that forecasts crop production for the wet and dry seasons, and some in-house reviews hosted by the research 
institutes. Only a few states still hold research-extension Monthly Technology Review Meetings, monthly meetings with ADPs to discuss new technologies, and their uptake chaired by the Institute for Agricultural Research (FMARD, 2016). A few different states do hold fortnightly trainings, but with limited contact with research institutes or the input from the technology review meetings. Moreover, all coordination meetings suffer from low participation of extension agents, farmers, and private-sector representatives. Extension agents usually do not have funding to travel for meetings.

\section{CONCLUSION}

This paper has looked at the existing capacities and management of the pluralistic Nigerian extension system. Capacities and management are important components of extension, providing the framework, tools, and facilities to implement programmes. They include human and physical resources, education and training, skills and capabilities, coordination, and programme financing.

At the individual level, extension agents receive adequate foundational education, but most do not receive additional training or continuing education unless they are attached to some donorfunded programme. Professionalism mechanisms such as certification and regulation are also lacking.

With regards to the organisational level, Nigerian extension services do not have adequate human resources. One bright spot is the attempt to bring in young graduates through the $\mathrm{N}$ Power Agro programme. However, once the requisite human resources are in place, operational funds are also needed for them to perform their functions. Some states have been providing additional incentives and support such as motorcycles. In addition, performance management systems are lacking.

At the system level, there are supportive policies and institutions in place so support and strengthen extension. Coordination mechanisms exist, however, without resources they cannot function properly.

Nigeria has the infrastructure and mechanisms for a well-functioning extension system. Due to the federal system and the pluralistic nature of extension, coordination is a major issue. Adequate resourcing of coordination mechanisms, as well as operational funds for extension agents should be addressed through cost-sharing mechanisms with various actors or other innovative financing mechanisms. Professionalism will also go a long way in raising the profile, along with the necessary resources of agricultural extension in Nigeria.

\section{RECOMMENDATIONS}

As a result of the findings, the following recommendations are given to improve organisational capacity and management of extension in Nigeria:

1. Reform and expand extension agents' basic training and continuing education to increase skills, research and job motivation, including:

a. Establishing minimum training standards paired with easy access to remedial training for female and male staff members. 
b. Expanding training content beyond basic agronomy into post-harvest processing and marketing of key crops, business skills, and functional skills (such as mobilisation, communication and facilitation).

c. Training NAERLS and/ or selected ADPs on low-cost ICT-enabled extension strategies.

2. Establish a performance-based management system for ADP staff linked to salaries and promotions, including:

a. A small number of tangible key performance indicators linked to goals of extension, namely farmer satisfaction, adoption, productivity, and welfare.

b. Rewards based on achieving certain targets.

3. Leverage and equip N-Power staff to assist with Agricultural Performance Survey of NAERLS nationwide. This information could also be used for improving extension and other agricultural programmes across the country by both the public and private sectors in Nigeria as well as donor projects.

\section{ACKNOWLEDGEMENT}

This work was supported by the United States Agency for International Development (USAID) Feed the Future Programme under USAID Cooperative Agreement No. AID-OAA-L-16-0002.

\section{REFERENCES}

AFRICAN DEVELOPMENT BANK (ADB), 2013. Strategic Environmental and Social Assessment (SESA): Executive summary. Abuja, Nigeria.

AGRICULTURAL SCIENCE AND TECHNOLOGY INDICATORS (ASTI), 2014. Agricultural R\&D indicators factsheet: Nigeria. Washington D.C., United States of America.

ARY, D., JACOBS, L.C. \& RAZAVIEH, A., 1996. Introduction to research education. 5th ed. Orlando: Harcourt Brace College.

AUTA, S.J. \& DAFWANG, I.I., 2010. The Agricultural Development Projects (ADPs) in Nigeria: Status and policy. Res. J. Agric. \& Biol. Sci., 6(2):138-143.

BIRNER, R., DAVIS, K., PENDER, J., NKONYA, E., ANANDAJAYASEKERAM, P., EKBOIR, J., MBABU, A., SPIELMAN, D., HORNA, D., BENIN, S. \& COHEN, M., 2009. From best practice to best fit: A framework for analyzing agricultural advisory services worldwide. J. Agric. Educ. Ext., 15(4):341-355.

BERTUCCI, G. \& JEMIAI, Y., 2000. Public sector reform revisited in the context of globalization. UN Division for Economics and Public Administration. New York, United States of America.

DAVIS, K. \& SULAIMAN, R.V., 2014. The new extensionist: Roles and capacities to strengthen extension and advisory services. J. Agric. Educ. Ext., 21(3):6-18.

FEDERAL GOVERNMENT OF NIGERIA (FGN), 2016. N-Power volunteer corps programmes. Available from: http://www.npower.gov.ng/n-corps.html

FEDERAL MINISTRY OF AGRICULTURE AND RURAL DEVELOPMENT (FMARD), 2016. The Agriculture Promotion Policy (2016-2020): Building on the successes of the ATA, closing key gaps. Abuja, Nigeria. 
S. Afr. J. Agric. Ext.

Vol. 47 No. 2, 2019: 118 - 127

http://dx.doi.org/10.17159/2413-3221/2019/v47n2a508
Davis, Lion,

Arokoyo

(License: CC BY 4.0)

FOOD AND AGRICULTURE ORGANIZATION (FAO), 2016. AQUASTAT country factsheet: Nigeria. Rome, Italy.

HUBER, S., DAVIS, K. \& LION, K., 2017. Nigeria: In-depth assessment of extension and advisory services. DLEC. Washington, D.C., United States of America.

MATSILELE, T., 2017. How big is Nigeria's food import bill? Available from: http://www.cnbcafrica.com/news/western-africa/2016/01/20/audu-ogbeh-nigeria-kolamasha/\#

SASAKAWA AFRICA FUND FOR EXTENSION EDUCATION (SAFE), 2017. SAFE student statistics. Available from: http://www.safe-africa.org/Student\%20Statistics.php

TECHNICAL CENTER FOR AGRICULTURAL AND RURAL COOPERATION (CTA), 2011. A case study report on Nigeria's agricultural extension and advisory system. Wageningen, Netherlands.

WORLD BANK, 2016. Implementation completion and results report for a third national Fadama development (Fadama III) project. Washington, D.C., United States of America. 
